\title{
Energy conservation project funding in commercial building: an expenditure or investment?
}

Shaikh Samsher Ali, Ruchi Tyagi, Ragini Chauhan

Department of Human Resource \& Organizational Behavior, School of Business, University of Petroleum \& Energy Studies, India

\begin{tabular}{l} 
Article Info \\
\hline Article history: \\
Received Jun 23, 2018 \\
Revised Aug 30, 2018 \\
Accepted Oct 3, 2018 \\
\hline
\end{tabular}

\section{Keywords:}

Commercial buildings

Energy conservation measures

Project funding

\begin{abstract}
Energy conservation is an unnecessary expenditure and considered as a less important operational activity in many third world countries, particularly in India. The review of literature on the energy conservation project funding identifies that unclear management vision and policy for energy conservation is one of the reason for its back seat. Energy Conservation is supposed to be a top-down approach, in reality, a procurement manager is obliged to buy based on L1 policy (Lowest quoted price). Most of the Energy Conservation Measures (ECM) are not available at lowest quoted price. Therefore, Energy Conservation Measures (ECM) turn out to be a document formality rather than practice. The paper highlights the need for a paradigm shift on Energy conservation project from an expenditure to an investment. The Energy Conservation Project is an investment that will continue to give a return as long as the equipment is in operation or the facility is functional. This calls for amendments in Energy Policies and Project Guidelines for swift that there are no conflicts between the departments for implementing the energy conservation projects.
\end{abstract}

Copyright $(2019$ Institute of Advanced Engineering and Science. All rights reserved.

\section{Corresponding Author:}

Shaikh Samsher Ali,

Department of Human Resource \& Organizational Behavior,

School of Business, University of Petroleum \& Energy Studies, India.

Email: sams586@yahoo.co.in

\section{INTRODUCTION}

The present day work culture is highly mechanized. For performing any work, energy is required. As per the basic Law of Energy, not all the energy used goes into doing the job but some of it converts into heat and is wasted. Energy is one of the prerequisites for any activity. That is why economists place it at par with other basic requirements like land, labour, capital and enterprise. Energy is a limited resource and that is why it is important to optimize its usage. Optimizing the utilization of energy in the scientific and non-scientific manner is conservation of energy in a simple language [1]. Energy is sourced from Mother Nature. The reserve is limited and will surely run out of its reservoir sometimes in future. Electrical power is generated using this reserve energy. Every country whether developed or under-developed should be concerned about this limited reserve and therefore there is a need for optimization of its utilization. India can play a leading role at the world stage for energy conservation since India has both manpower and brain power, which are prerequisite for such activity [2]. Saving energy will have the dual impact, i.e. Monitory gain and excess capacity to meet new demands. Energy conservation is everyone's business as it is applicable to industrial and non-industrial applications [3]. The focus of the present study is Energy Conservation Project Funding in India. The purpose of this study is to identify the considerations of energy conservation project funding for its successful implementation.

Executing project to implement Energy Conservation Measures may not be as simple as it appears to be on its face value. There are bottlenecks in project implementation like any other projects but with a 
difference. These are clearly highlighted in "Barriers to Energy Efficiency - review and policy guidance" by UNEP (United Nations Environment Programme) in 2006. India, being energy-starved developing country with high dependence on imported crude oil, has failed to implement any significant initiative towards conservation of energy. Easy availability, faulty subsidize pricing policy, limited competitiveness on the industry are some of the possible reasons behind such lackluster attitude of the major stakeholders [2].

The study shows energy conservation is not "One pill for all" approach. It should be a tailor-made approach based on scientific evaluation of the existing system and operational practices. If it is done on "Performance Contracting" model, which is popularly, known as the ESCO model then it is not only economically viable but also technically feasible [4]. Energy conservation project executed on performance contracting basis lay minimum financial burden on any organization. Thus, there is a need to understand the basic elements of energy conservation and performance contracting.

\section{ENERGY CONSERVATION}

The importance of energy derives from its input to production and consumption activities in an economy, activities that in turn derive from society's choices for goods and services. To provide these goods and services, energy is used in combination with other resources [5]-[9]. Research has shown that reduction in the amount of energy use per unit of economic activity is not only technologically possible but is desirable according to economic and other criteria. These reductions in energy intensity belong to a set of activities known as energy conservation [10].

\subsection{Why energy conservation?}

It is evident from the above discussion that energy conservation is not only supportive to operational excellence and relief to operational budget at the operating end but also helps us in preserving the natural resources and reducing GHG emission [3]. Therefore, it will have an impact on operations, expenditure and performance. Efficient utilization of energy makes the machines more efficient and an efficient machine gives better performance. Machines operating efficiently under less duress will have fewer breakdowns, which translate into more output with better energy intensity [11]. Overall, an efficient operation will not only create a safe work environment but will also help in grooming a motivated workforce striving for economical operations.

Energy Conservation will have the direct and indirect impact on Operational Expenditure. The reduced energy bill will mean a direct addition of the difference between previous and present energy bill to the company's bottom line. The motivated workforce will help in achieving bigger operational/production targets thereby, making the operation more competitive. Fewer breakdowns will not only enhance productivity but will also reduce maintenance cost. In case of budgetary constraints, the project implementation cost maybe supported by money saved from energy conservation projects, The Airport energy conservation studies are classic example to it [12]. Operational excellence coupled with reduced operational cost will enhance the performance of any organization striving for growth [13]. Past studies on implementation of energy conservation highlights positive impact on employee performance [14], [15].

\subsection{Applicability of energy conservation}

As stated above the reductions in the amount of energy use per unit of economic activity will encompass every facility using energy. This usage of energy can be in any form, i.e. Electricity, Fuel, Thermal, Water etc. and will cover every facility engaged in Manufacturing, Education, Government Activities, Warehousing, Commercial Activities etc. [16]-[18].

\subsection{Practical difficulties to energy conservation}

Energy Conservation in any organization should be everyone's responsibility as everyone uses energy directly (Operating machine) or indirectly (Occupying the facility space) to do his or her work. Many a time it is misunderstood to be the responsibility of only operation and maintenance people of the facility [19]. It becomes more complicated in smaller facility where there is no dedicated operation and maintenance staff. Ideally speaking energy conservation in any facility should be a Top-Down approach with management initiatives [20]. Unfortunately, it does not happen particularly in smaller organizations operating with budgetary constraint.

Authorities are still working to improve the framework and methodology for PAT (Perform, Achieve and Trade) introduced in India. Inadequate guidelines or suggested measures by BEE (Bureau of Energy Efficiency) for energy cost reduction needs improvement. Measurement and verification process in India is yet to be at par with international Measurement and Verification protocol as it is a key validating tool [21].

Energy conservation project funding in commercial building: an expenditure... (Shaikh Samsher Ali) 


\subsection{The bigger picture}

Energy Conservation has a cascading impact on an organization's operation and therefore on Operational Budget at the micro level. It helps us in optimizing the use of energy and conserving natural resources as energy comes from Mother Nature. It has also a definite impact on the macro level when we talk about Industry, Country and Globalization.

At the lower end of the strata that is, Sectoral level like residential, industry, commercial and transportation etc. benefits will be of reduced operating energy cost besides many indirect benefits. At the National level, the benefits will be like a positive impact on GDP, Job creation and GHG (Green House Gas) emission reduction. Talking about International level the benefits will be on export market and reduced energy prices [22].

\section{OPTIONS AVAILABLE FOR ENERGY CONSERVATION}

There are various options available for implementation of energy conservation project from fund requirement point of view. These can be High-Cost, Mid-Cost and Low-Cost Options [23]-[25] depending upon what kind of activities are involved to enhance the efficiency and what kind of operations it is, i.e. Existing Operation, New Operation etc.

\subsection{Technological excellence}

Technological Excellence is to implement the latest technology having better performance. These can be better technology, efficient machine, optimization of operations. If it is a new operation then the latest and advanced version of the system can be opted. If it is an existing operation, then the best system compatible to work with the existing system for better performance should be opted. The above are High-Cost Energy Conservation Measures. The target set by Govt. of India under PAT (Perform, Achieve and Trade) Scheme for the year 2014-15 are as follows [26]:

a. Annual fuel savings in excess of 23 million toe (Tons of Oil Equivalent),

b. Cumulative avoided electricity capacity addition of 19,000 MW,

c. CO2emission mitigation of 98 million tons per year.

\subsection{Operational fine tuning}

Operational Fine Tuning is mostly for existing operations where activities like Addition and Alterations, Fine Tuning, Change in Work Process etc. make the existing operations more efficient by enhancing the throughput [27]. As they involve certain cost, they are Mid-Cost Energy Conservation Measures.

\subsection{User impact}

It is a fact that equipment / machine actually consumes the power in order to give the desired output, but the same equipment / machine doing similar activities can consume a different amount of energy at different locations. It is because of human intervention. Human influences the energy consumption of equipment / machines it happens mainly due to ignorance and careless attitude [28]. We do many things in our daily lives in a routine manner or as a matter of habit thinking that is the right way to do the job [29]. It may not be so unless someone points out the flaws. If someone tells the right way to do the job or help in identifying what is being ignored thinking as less important, that can make an impact on energy consumption [30]. Similarly, the management of any organization can also come up with certain administrative guidelines about Dos and Don'ts when it comes to energy usage and that can help in reducing the energy consumption [31]. The above measures involve changes in energy user's behaviour. They are Low-Cost Energy Conservation Measures.

\section{ECONOMIC CONSIDERATIONS FOR IMPLEMENTING ENERGY CONSERVATION OPTIONS}

Economic consideration will definitely have an impact irrespective of the energy conservation options one may choose to implement. If one sees it as expenditure, then the consideration is to undertake whatever minimum is needed to reduce the consumption. On the contrary, if it is seen as an investment then the return on that investment can create a paradigm shift [32].

An overview of energy savings achieved by industrial units participated in the Ministry of Power, Govt. of India, award scheme from 1999 to 2005 (seven years) in support of economic consideration. There were 120 to 311 units which showed a total investment of ₹ 66.71 million and a total savings of ₹ 40.43 million is made in in 7 Years. Thus, the total electrical energy saved in 7 years is 4.527 million units and Equivalent avoided capacity is $865 \mathrm{MW}$ [33].

Int J Pow Elec \& Dri Syst, Vol. 10, No. 1, March 2019：504-513 
Point is to be noted that it is just not ₹ 40.43 million savings against the project implementation cost of ₹ 66.71 million with 19 months payback period but also saving of 4,527 Million units of electricity that is equivalent to avoiding setting up of $865 \mathrm{MW}$ capacity power plants besides other savings. Within the World Bank, lending for energy efficiency has become a mainstreamed business line, with more than US\$5.2 billion lent over the five fiscal years ending June 30, 2015 [34]. Therefore, implementation of energy conservation projects will have both direct and indirect benefits.

\subsection{Direct benefit}

Some of the direct benefits are like savings in monthly energy bill which can easily be quantified and return on investment can be worked out. Various case studies suggest that the return on investment is very attractive. Studies show the payback for Low-Cost Energy Conservation measures is less than 1 year, MidCost measures is 1-2 years and High-Cost measures will be 2-5 years [12], [23] depending upon the application, hours of operations and system configurations etc. Studies in the USA indicate that the dependence on Demand Side Management (DSM) incentives is gradually decreasing since 1995. It is estimated that industry investment for energy-efficiency related services reached US\$2 billion in 2000 following a decade of strong growth [35]. U.S. ESCOs generated $\sim \$ 23$ billion in direct benefits at projects installed from 1990-2008 [36].

\subsection{Indirect benefit}

It may not be possible to correctly quantify the amount of savings in indirect benefits as the impacts are more felt than seen. It is more qualitative than quantitative in nature and influences the moral of the people. The US-ESCO (Energy Servicing Company) industry is considered as the most successful model for the private sector delivery of energy efficient services. Actual performance of the ESCO industry is documented in order to provide policymakers and investors with objective information and customers with a resource for benchmarking future projects relative to industry performance [16].

\section{BARRIERS TO IMPLEMENT ENERGY CONSERVATION OPTIONS}

\subsection{Budgetary constraint}

Opex is a constraint in any organization and it becomes more critical when it is considered to be an expenditure. Under such circumstances, energy conservation projects take the back seat and conveniently forgotten by the people empowered to grant the fund. Energy-efficient technologies are more expensive to procure compared to alternative technologies [37]. Obtaining additional fund for investing in energy-efficient technology is usually problematic. Low liquidity and limited access to capital can arise due to restrictions on lending money [38]. Sometimes such restrictions are due to the internal policy of the organization. The ESCOs (Energy Servicing Company) in India are small and have limited financial resources. Very few ESCO projects can be financed with the ESCO's own resources. It is almost impossible to raise fund based on their actual balance sheet. The Financial institutes and banks interest in ESCO projects remain low due to various factors like financial conditions of ESCOs / end users, lack of technical expertise to evaluate Energy Efficiency project's potential by banks security concerns etc. [33].

\subsection{Management apathy}

Studies suggest that any energy conservation program can reach its maximum potential level if it is driven by the management [4], [33], [39], [40]. Because it not only gives the vision but also gives the moral authority and budgetary support for the successful implementation of the program. Below is one such suggested model [41]. Organizational structure and energy management program as shown in Figure 1.


Figure 1. Organizational structure and energy management program 
Organizations concentrate solely on its core business as a general practice. Lack of dedicated personnel with a focus on energy issues, scarcity of energy expertise, budgetary constraint and limited investment resources are some of the reasons to avoid any energy conservation project [42].

\subsection{Lack of understanding}

It is like a double-edged sword. People authorized to take the decision are either not having the necessary information or having distorted information / misinformation that leads to confusions rather than having clarity to take the call. People working on the equipment / machines are mostly junior level employees not empowered to take any policy / funding decision but having complete information. There is a distinct communication gap between the senior management and the junior management when it comes to taking the actionable decision on energy conservation projects [43]. Very often, it happens that after spending a lot of time and effort by ESCO it is realized that although the customer is willing to implement the project, no one is willing to finance the customer for implementing a potential project. This puts a heavy financial burden on small ESCOs [33].

\subsection{Unclear policy}

A clear policy with a vision can help in implementing any energy conservation program. The study shows either there is unclear policy or lack of vision for energy conservation program [26]. Perhaps it is lack of apathy or lost priority for the management in most of the organization. Today when the top management in any organization burning the midnight oil, doing all possible jugglery to reduce the operating cost completely ignores huge potential available at their disposal in the form of energy conservation. The fact is most of them do not know the energy cost of their per unit throughput [44], [45]. Countries like USA, UK, China, Japan, Netherland, Denmark, Canada and India have Energy Policy applicable for respective countries. Energy efficiency policies like Pricing Policy, Institutional Development Policy and Energy Efficiency Technology Policy have been developed and implemented in India [1]. It is a fact that energy efficient technology is expensive and at the same time pricing policy advocates for L1 (Lowest quoted price) concept for procurement. It is a conflict in itself, which needs immediate correction.

\section{WHAT IS PROVEN PRACTICE FOR ECONOMIC WAY OF ENERGY CONSERVATION? \\ 6.1. ESCO model}

Broadly speaking this energy conservation approach has four main elements that are the key factors for successful implementation. These are Energy Audit, Identification of appropriate Energy Conservation Measures (ECM) and Funding, Implementation of the ECMs and Measurement and Verification (M\&V) protocol to monitor the expected savings and its maintenance [21]. ESCO model operates on the principle of "Performance Contracting". It is legally accountable performance contract based on a detailed energy audit, its analysis, findings and recommendations for energy conservations in any facility [35].

Modus-Operandi of ESCO is "Pay as you save". Which means the project is funded and implemented by the savings from the implementation of the project. Saving is calculated based on the difference between the baseline energy cost and after implementation of energy cost. Savings can also be on sharing basis between the client and ESCO depending upon the contract period and proportion of sharing. It is mostly Tri-Party agreement [35]. Client is the organization where the energy conservation project is to be implemented and is the first party. ESCO is the independent entity engaged in Energy Audit and Project Implementation to realize the energy savings and is the second party. OEM (Original Equipment Manufacturer) or any other organization that will either supply the energy conservation measures or fund for procuring the same and is the third party.

\subsection{Procedure of implementation}

It is scientific and systematic procedure where energy conservation measures are implemented in such a way that the impacts are mutually additive. So that it will have a positive financial impact in procuring the subsequent energy conservation measures. The suggested procedure is highlighted bellow [41]. Typical energy audit and implementation program as shown in Figure 2.

Int J Pow Elec \& Dri Syst, Vol. 10, No. 1, March 2019: $504-513$ 


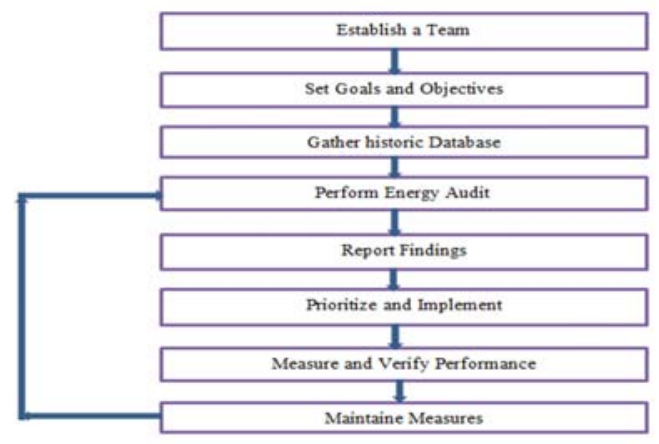

Figure 2. Typical energy audit and implementation program

The whole procedure is carried out by qualified, experienced and competent professionals in step by step manner. The first step is to collect the historic operational data and draw the baseline. The second step is to measure various operational parameters, record and analyze the data. In the third step, operational efficiency is evaluated and all Energy Conservation Measures (ECM) are identified. An action plan is drawn about how to implement the ECMs, implementation cost and cost-benefit analysis. In the final step, the ECMs are implemented and the performances are measured and verified through an established Measurement and Verification $(\mathrm{M} \& \mathrm{~V})$ protocol.

\subsection{Financing}

ESCO projects in India are generally implemented under the guaranteed savings scheme and shared savings scheme. The Indian Renewable Energy Development Agency Ltd. (IREDA) is an organization in India for financing Energy Efficiency projects. The World Bank has extended a Line of Credit to IREDA for developing and financing energy efficiency and conservation projects that include project implemented in the ESCO model. The loan could be up to $70 \%$ of the project cost with an interest rate lower than that offered by any commercial bank and has a maximum moratorium of 2 years for repayment [33]. The commercial banks in India are generally apprehensive about funding Energy Efficiency projects. Recently five prominent banks in India, State Bank of India (SBI), Canara Bank, Union Bank of India, Bank of India and Bank of Baroda have launched Energy Efficiency schemes for SMEs. The schemes are addressed towards their existing SME clients and for small projects up to USD 22,000 [33].

\section{METHODOLOGY FOR FUNDING ESCO PROJECTS}

The First step towards funding any ESCO project is to identify the Energy Conservation Measures (ECM) [41], [46] that is applicable keeping the long-term operational requirements of the facility. These ECMs are categorized based on their cascading impacts for deciding the sequence of ECM implementation for energy conservation [8]. Cost-benefit analysis is done taking the cost of ECMs, energy saved from the ECMs, methodology opted for sharing the saving if any and the agreed project duration [1]. The complete projected cash flow is plotted in excel sheet and cash flow charts are prepared for ease of understanding by the management. The project concept and the cash flow situation along with project SWOT analysis are presented to the management for the project approval and fund authorization [2], [47]. Once the project is approved and the fund is allotted an escrow account is opened to manage and control the complete cash flow for the entireproject duration.

\section{RESULTS AND DISCUSSIONS}

\subsection{Benefits of performance contracting (Esco Model)}

It is not only ease of implementation but will also have both technical and economic benefits.

\subsubsection{Technical}

Technically speaking the whole system will be more energy efficient after the energy conservation measures are implemented. An efficient system will perform better. Thereby, less breakdown and more productivity leading to a positive impact. ESCOs are often seen as important and effective change agents in capturing the opportunity to curb energy demand and technological excellence through increased efficiency [20], [48], [49].

Energy conservation project funding in commercial building: an expenditure... (Shaikh Samsher Ali) 


\subsubsection{Commercial}

An energy efficient system will require less Opex and thereby an increase in the organization's bottom-line. Higher productivity will lead to an increased top-line. Overall the profitability of the organization will increase. A profitable and growing organization will create a motivated and satisfied team striving for greater heights. The Indian Government's Bureau of Energy Efficiency (BEE) has introduced the 'Perform, Achieve and Trade' (PAT) scheme in 2011 to give a boost to ESCO projects. Most energy efficiency potential lies in private factories and buildings, so the private sector should be involved at the start of any initiative, whether as an end user, a potential implementer, or a possible financier [34]. Energy efficiency choice primarily involves investment decisions that will have a tradeoff between higher initial capital costs and uncertain lower future energy operating costs, when we see it from an economic perspective. In simple term, the initial cost is the difference between the procurement and installation cost of a relatively energy-efficient product/system and the cost of an otherwise equivalent product/system that provides the same services but use more energy. The decision of whether to make the energy efficient investment requires weighing this initial capital cost against the expected future savings. It is comparison of initial cost-plus lifetime operating cost between a conventional system and the energy efficient system [1], [50]-[52].

\subsection{Payback/return on investment of performance contracting (Esco Model)}

If we consider the energy conservation project implementation cost as an investment, then the return from that investment is very attractive from the economic point of view. Below are few such projects with payback details to justify that it is not an expenditure but an investment as the project cost is recovered in a short span of time but the return from that investment continue to get realized so long the equipment is in operation / facility is functional.

a. Energy Conservation Measures implementation on Fans, Pumps, Cooling Towers, Lights and Building Automation System cost was Low to Mid-Cost with a payback period of $2-5$ years giving $5-15 \%$ of energy savings in Airports [12], [53].

b. Energy Conservation Measure implementation on lights had Mid-Cost with a payback of 3 years giving $50 \%$ energy savings in lighting application in educational institute [23].

\subsection{Investment opportunities in energy efficiency projects in india}

Mr. Satish Sabharwal, BEE, GOI, [54] highlighted the energy savings potential in India in one of his presentations to promote energy conservation. Point is to be noted that he termed the implementation cost as an "Investment" and not "Expenditure". Bellow is the summary of Investment opportunity in Energy Efficiency projects in India. Table 1 shows investment opportunity in energy efficiency projects in India.

Table 1. Investment opportunity in energy efficiency projects in India

\begin{tabular}{ccc}
\hline Market Type & Investment (₹ Billion) & Avoided MW \\
\hline Industrial & 121 & 7000 \\
Commercial & 6 & 553 \\
Municipal & 13 & 1655 \\
Total & 140 & 9208 \\
\hline
\end{tabular}

The ESCO industry in the USA continues to grow with estimated revenues of $\$ 4.1$ billion in 2008 despite a general downturn in the broader economy. In the USA, energy conservation is considered as an Industry that has huge growth potential [43], [55]

\section{CONCLUSIONS}

It is evident from the facts of case studies, reports and policy initiatives that energy conservation is need of the hour in order to remain competitive in the Indian market. However, due to prejudice or lack of understanding management in most of the Indian organizations do not give due importance to energy conservation programs. Studies show that it is a low hanging fruit that goes unnoticed most of the time by the management in them strive to find means and ways to reduce the operations cost [1], [56], [20]. Maybe it is the mindset of the management to see it as an unnecessary, uncalled for expenditure. Should they see it as an investment then they will not only reap the benefits of this low hanging fruit to reduce their operation cost but will also add a sizable amount of profit to the business. It is time to have the paradigm shift in energy conservation in India. Vision, policy and guidelines should not be limited only on paper. Energy conservation program in every organization should be a top-down approach with clear guidelines. Perhaps the very first guidelines to change will be the procurement policy. L1 concept (Lowest quoted price) can never be the criteria 
for such projects because technology should have the priority over price when we talk about energy conservation. Perhaps, it will also make it easy for funding organizations to lend money for such energy conservation projects in India.

\section{REFERENCES}

[1] Kenneth Gillingham, Richard G. Newell, Karen Palmer, "Energy Efficiency Economics and Policy", Discussion Paper, Resources, 2009.

[2] Dipankar Dey, "Energy Efficiency Initiatives: Indian Experience, Energy and Sustainable Development in India, Sustainable Energy Watch 2005 Report", Helio International, France, 2005.

[3] William R. Morrow III, Ali Hasanbeigi, Jayant Sathaye, Tengfang Xu, "Assessment of energy efficiency improvement and $\mathrm{CO} 2$ emission reduction potentials in India's cement and iron \& steel industries", Journal of Cleaner Production 65, 131e141, http://dx.doi.org/10.1016/j.jclepro.2013.07.022, 2014

[4] UNEP, "Barriers to Energy Efficiency - review and policy guidance", www.energyefficiencyasia.org, 2006.

[5] Gesche Margarethe Huebner, Justine Cooper, Keith Jones, "Domestic energy consumption - What role do comfort, habit and knowledge about the heating system play?", Energy and Buildings 66, 626-636, http://dx.doi.org/10.1016/j.enbuild.2013.07.043, 2013.

[6] Tsai-Hsiang Chen, Nien-Che Yang1, "Simplified annual energy loss evaluation method for branch circuits of a home or building", Energy and Buildings 42, 2281-2288, doi:10.1016/j.enbuild.2010.07.008, 2010.

[7] S.L. Wong, Kevin K.W. Wan, Danny H.W. Li, Joseph C. Lam, "Impact of climate change on residential building envelope cooling loads in subtropical climates", Energy and Buildings 42, 2098-2103, doi:10.1016/j.enbuild.2010.06.021, 2010.

[8] Nelson Fumo, Pedro Mago, Rogelio Luck, "Methodology to estimate building energy consumption using Energy Plus Benchmark Models", Energy and Buildings 42, 2331-2337, doi:10.1016/j.enbuild.2010.07.027, 2010.

[9] Shu Haiwena, Duanmu Lina, Li Xianglia, Zhu Yingxinb, "Quasi-dynamic energy-saving judgment of electric-driven seawater source heat pump district heating system over boiler house district heating system”, Energy and Buildings 42,2424-2430, doi:10.1016/j.enbuild.2010.08.012, 2010.

[10] Eulalia Jadraque Gago, Javier Ordónez García, Antonio Espín Estrella, "Development of an energy model for the residential sector: Electricity consumption in Andalusia, Spain", Energy and Buildings 43,1315-1321, doi:10.1016/j.enbuild.2011.01.016, 2011.

[11] 11 Monica Dutta, Saptarshi Mukherjee, "An outlook into energy consumption in large scale industries in India: The cases of steel, aluminium and cement”, Energy Policy 38, 7286-7298, doi:10.1016/j.enpol.2010.07.056, 2010.

[12] 12 Craig R. Lau, Joel T. Stromgren, Daniel J. Green, “Airport Energy Efficiency and Cost Reduction, A Synthesis of Airport Practice", Transportation Research Board of the National Academies. Federal Aviation Administration, Transportation Research Board Washington, D.C., http://www.airport-energy.org/ACRP-reports/ACRP021irport_Energy_Efficiency_and_Cost_Reduction.pdf, 2010.

[13] 13 T. Ramesha, Ravi Prakasha, K.K. Shukla, "Life cycle energy analysis of buildings: An overview", Energy and Buildings 42, 1592-1600, doi:10.1016/j.enbuild.2010.05.007, 2010.

[14] 14 Arthur H. Rosenfeld, "Notes on residential fuel use: Thermostat and window management", Energy and building, Volume 1, Issue 1, Pages 99-101. https://doi.org/10.1016/0378-7788(77)90020-2, May 1977.

[15] 15 Sam H. Schurr, "Energy Efficiency and Productive Efficiency: Some thoughts based on American experience". The Energy Journal, Vol.3, No. 3, pp. 3-14, , July 1982. http://www.jstor.org/stable/41322143

[16] 16 Charles A.Goldman, Osborn, Julie G, Hopper, Nicole C, Singer, Terry E, "Market trends in the US ESCO industry: Result from the NAESCO database Projects", US Department of Energy, Office of Scientific and Technical Information, DOI: 10.2172/799576, 2012.

[17] 17 Carlos Alberto Mariotoni, Paulo Roberto Santos, "Household-electric equipment diffusion and the impacts in the demand of residential electric energy in Brazil", Energy and Buildings 37, 853-857, doi:10.1016/j.enbuild.2004.11.004, 2005.

[18] 18 Szymon Ogonowski, "Modeling of the heating system in small building for control", Energy and Buildings 42, 1510-1516, doi:10.1016/j.enbuild.2010.03.021, 2010.

[19] 19 Zhen Li, Xiao-Hua Liub, Zhang Lunb, Yi Jiangb, "Analysis on the ideal energy efficiency of dehumidification process from buildings", Energy and Buildings 42, 2014-2020, doi:10.1016/j.enbuild.2010.06.008, 2010.

[20] 20 Katie Lindgren Soroy, Lars J. Nilsson, "Building a business to close the efficiency gap: The Swedish ESCO Experience", Energy Efficiency, Volume 3, Issue 3, pp 237-256, September 2010.

[21] 21 Energetica India, "Energy Efficiency in India: PAT Scheme - They way forward", Energetica India, 2014.

[22] 22 Institute for European Environmental Policy (IEEP), "Review of costs and benefits of energy savings: Task 1 Report 'Energy Saving 2030”, http://www.europeanenvironmentalpolicy.eu, IEE,P 2013.

[23] 23 Biswas B, S. Mukherjee, A. Ghosh, "Conservation of Energy: a Case Study on Energy Conservation in Campus Lighting in an Institution", International Journal of Modern Engineering Research (IJMER), Vol.3, Issue.4, pp-19391941, ISSN: 2249-6645. http://www.ijmer.com/papers/Vol3_Issue4/AN3419391941.pdf, Jul - Aug. 2013

[24] 24 Mohd Hafizal Ishak, Ibrahim Sipan, Maimunah Sapri, Abdul Hamid Mar Iman, David Martin, "Estimating potential saving with energy consumption behavior model in higher education institutions", Sustainable Environment Research, 1- 6, http://dx.doi.org/10.1016/j.serj.2016.04.017, 2016.

[25] 25 Linda Steg, Charles Vlek, "Encouraging pro-environmental behaviour: An integrative review and research agenda", Journal of Environmental Psychology 29, 309-317, doi:10.1016/j.jenvp.2008.10.004, 2009.

Energy conservation project funding in commercial building: an expenditure... (Shaikh Samsher Ali) 
[26] 26 Bureau of Energy Efficiency, "Perform, Achieve \& Trade (PAT)", https://beeindia.gov.in/

[27] 27 Nathalie Trudeau, Cecilia Tam Dagmar Graczyk, Peter Taylor, "Energy Transition for industry: India and the Global context", International Energy Agency, 2011.

[28] 28 M.H. Bala Subrahmanya, "Industry features and energy efficiency in Indian small enterprises - A case study of auto ancillaries and brick makers", International Journal of Energy Sector Management, Vol. 1 No. 2, pp. 160-174, DOI 10.1108/17506220710761573, 2007.

[29] 29 Lukas Weber, "Some reflections on barriers to the efficient use of Energy", Elsevier, Energy Policy, Vol. 25, No. 10, pp. 833-835, PII:S0301-4215(97)00084-0, 1997.

[30] 30 Clive Seligman John, M. Darley Lawrence J.Becker, "Behavioral approaches to residential energy conservation", Energy and Building, Volume 1, Issue 3, Pages 325-337. https://doi.org/10.1016/0378-7788(78)90012-9, April 1978.

[31] 31 John F. Busch, "A tale of two populations: thermal comfort in air-conditioned and naturally ventilated office in Thailand", Energy and Building, Volume 18, Issues 3-4, Pages 235-249. https://doi.org/10.1016/03787788(92)90016-A, 1992.

[32] 32 Sanjay J Bhayani, "Determinant of Profitability in Indian cement Industry: An Economic Analysis", South Asian Journal of Management, https:/www.questia.com/library/journal/1P3-2281939121/determinant-of-profitability-inindian-cement-industry, 2009.

[33] 33 World Energy Council, "Case Studies on Energy Efficiency Policy and Measure", Energy Efficiency Policies and Indicators - ANNEX 1, 2008.

[34] 34 Jag Singh, "Why Energy Efficiency Matters and How to Scale it Up", Live Wire, World Bank group, 2016.

[35] 35 Charles A Goldman, Nicole C Hopper, Julie G Osborn, "Review of US ESCO Industry market trends: an empirical analysis of project data", Science Direct, Energy Policy, Volume 33, Issue 3, Pages 387-405, https://doi.org/10.1016/j.enpol.2003.08.008, , February 2005.

[36] 36 Peter H. Larsen, Charles A.Goldman, Andrew Satchwe, "Evolution of the US energy service company industry: Market size and project performance from 1990 - 2008", Science Direct, Energy Policy, Volume 50, Pages 802-820. https://doi.org/10.1016/j.enpol.2012.08.035, , November 2012.

[37] 37 Almeida, E. L., "Energy efficiency and the limits of market forces: The example of the electric motor market in France", Energy Policy, 26, 8, 643-653, ISSN 0301-4215, 1998.

[38] 38 Hirst, E., Brown, M. A, "Closing the efficiency gap: barriers to the efficient use of energy", Resources, Conservation and Recycling3, 4, 267-281, ISSN 0921-3449, 1990.

[39] 39 Leena Srivastava, "Energy Conservation Policy in India", TERI,

[40] 40 Patrik Thollander, Jenny Palm, Patrik Rohdin, "Categorizing Barriers to Energy Efficiency: An Interdisciplinary Perspective", Energy Efficiency.

[41] 41 E.A. Abdelaziz, R. Saidur, S. Mekhilef, "A review on energy saving strategies in industrial sector", 15 150-168, doi:10.1016/j.rser.2010.09.003, 2011.

[42] 42 Jenny Palm, "Placing barriers to industrial energy efficiency in a social context: a discussion of lifestyle categorization", Springer, Energy Efficiency, 2:263-270, DOI 10.1007/s12053-009-9042-1, 2009.

[43] 43 Andrew Satchwell, Charles Goldman, Peter Larsen, Donald Gilligan, Terry Singer, "A Survey of the U.S. ESCO Industry: Market Growth and Development from 2008 to 2011", https://escholarship.org/uc/item/2114b1bx, 2014.

[44] 44 Marvin J. Horowitz, "Electricity Intensity in the Commercial Sector: Market and Public Program Effects", The Energy Journal, Vol. 25, No. 2, pp. 115-137, http://www.jstor.org/stable/41323034, 2004.

[45] 45 Ronald J. Sutherland, "No Cost Efforts to Reduce Carbon Emissions in the U.S.: An Economic Perspective", The Energy Journal, Vol. 21, No. 3, pp. 89-112, http://www.jstor.org/stable/41322892, 2000.

[46] 46 David S. Loughran, Jonathan Kulick, "Demand-Side Management and Energy Efficiency in the United States", The Energy Journal, Vol. 25, No. 1, pp. 19-43, http://www.jstor.org/stable/41323019, 2004.

[47] 47 Nien-Che Yanga, Tsai-Hsiang Chenb, "Assessment of loss factor approach to energy loss evaluation for branch circuits or feeders of a dwelling unit or building", Energy and Buildings 48, 91-96, doi:10.1016/j.enbuild.2012.01.015, 2012.

[48] 48 Yuriy Semenovich Usynin, Dmitry Alexandrovich Sychev, Nikita Vadimovich Savosteenko, "Energy Saving in Pilger Mill Electric Drives. Complete Solution", International Journal of Power Electronics and Drive Systems (IJPEDS), Vol. 8, No. 4, pp. 1673-1681, December 2017.

[49] 49 Md. Mejbaul Haque, Md. Kamal Hossain, Md. Mortuza Ali, Md. Rafiqul Islam Sheikh, "Microcontroller based single phase digital prepaid energy meter for improved metering and billing system", International Journal of Power Electronics and Drive Systems (IJPEDS), Vol. 1, No. 2, pp. 139-147, December 2011.

[50] 50 Zulhelmi, Zulfikar, Agus Mulyadi, "An alternative power supply system during peak loads using solar cells", International Journal of Power Electronics and Drive Systems (IJPEDS), Vol.9, No. 3, pp. 1338-1348, September 2018.

[51] 51 Amanda Halim, Ahmad Fudholi, Stephen Phillips Kamaruzzaman Sopian, "Review on Optimised Configuration of Hybrid Solar-PV Diesel System for Off-Grid Rural Electrification", International Journal of Power Electronics and Drive Systems (IJPEDS), Vol. 9, No. 3, pp. 1374-1380, September 2018.

[52] 52 Syafii, Refdinal Nazir, "Performance and energy saving analysis of grid connected photovoltaic in West Sumatera", International Journal of Power Electronics and Drive Systems (IJPEDS), Vol. 7, No. 4, pp. 1348-1354, December 2016.

[53] 53 Gail S. Brager and Richard J.de Dear, “Thermal adaption in the building environment: a literature review”, Energy and Building, Volume 27, Issue 1, Pages 83-96. https://doi.org/10.1016/S0378-7788(97)00053-4, February 1998.

Int J Pow Elec \& Dri Syst, Vol. 10, No. 1, March 2019: $504-513$ 
[54] 54 Satish Sabharwal, "Lessons learned in Implementation of Energy Efficiency Policies in India", BEE, GOI. https://beeindia.gov.in/

[55] 55 Yigzaw G.Yohanis, Jayanta D.Mondol, Alan Wright and Brian Norton, "Real-Life energy use in UK: How occupancy and dwelling characteristics affect domestic energy use". Energy and Building, Volume 40, Issue 6, Pages 1053-1059. Volume 40, Issue 6, 2008, Pages 1053-1059, 2008.

[56] 56 European Business and Technology Center, "Energy Efficiency in India". www.ebtc.eu

\section{BIOGRAPHIES OF AUTHORS}
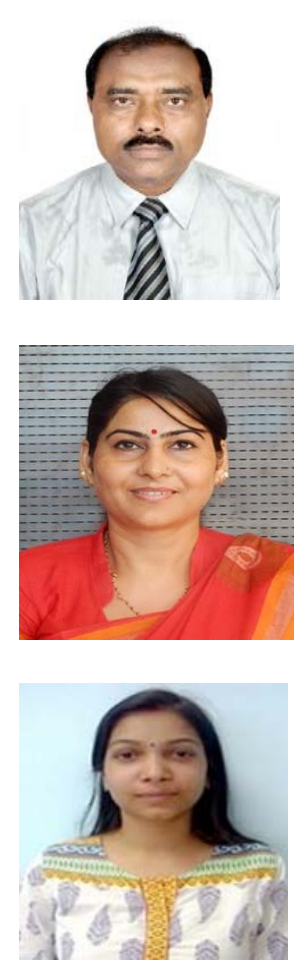

Shaikh Shamser Ali is an Ex-Indian Naval Artificer having 35 years hands-on experience in energy conservation, project management, operations and maintenance, sales and marketing, manufacturing and profit centre operations. He has worked in India, the UK and the Middle East in Marine, Oil and Gas, Utilities and Heavy Fabrications secto₹ He is a BEE Certified Energy Auditor and Energy Manager, PMI USA Certified Project Manager and Professional Engineer from UK chapter. Presently he is pursuing his $\mathrm{PhD}$ in energy conservation from University of Petroleum and Energy Studies at Dehradun. He has worked with 3 Energy Servicing Companies for over 10 years in India and abroad and presently working as a freelance energy conservation consultant with 3 companies engaged in energy conservation business in India.

Dr Ruchi Tyagi is a self-inspired, value driven and socio officially extremely well adjusted individual with 13 years of teaching and training experience of Post and undergraduate students at different reputed institutes. Presently, she is an Associate Professor and HOD, HR and OB Department at University of Petroleum \& Energy Studies, Dehradun, India. Her academic background is: MBA (HR), MJMC Degree, and $\mathrm{PhD}$ (Mnagement). She has been a speaker at Nizhny Institute of Business \& Management, Vladimir University, Pushkin State University, Kozminisky University, Herzenberg State Pedagogical University and Moscow State University (Deptt of Ethics). She has authored two books and has published many research papers in reputed journals.

Dr. Ragini is currently working as Assistant Professor at University of Petroleum and Energy Studies, Dehradun. She holds a Bachelor degree in Science, MBA in Human Resource and PhD in Management. Her Areas of interest include training and development, employee engagement and Emotional Intelligence. She has to her credit many research papers published in journals of national and international repute. 